Revista Eletrônica de Direito Processual - REDP.

Rio de Janeiro. Ano 10. Volume 17. Número 1. Janeiro a Junho de 2016

Periódico Semestral da Pós-Graduação Stricto Sensu em Direito Processual da UERJ

Patrono: José Carlos Barbosa Moreira. ISSN 1982-7636. pp. 46-66

http://www.e-publicacoes.uerj.br/index.php/redp/index

\title{
O SIGILO NO PROCESSO PENAL ESPANHOL ${ }^{1}$
}

\section{SECRECY IN THE SPANISH CRIMINAL PROCEDURE}

\section{Brenno Gimenes Cesca}

Mestre em Direito pela USP. Juiz de Direito no Estado de São Paulo. brennogc@gmail.com

RESUMO. Este trabalho analisa o sigilo no processo espanhol, esclarecendo, primeiramente, sua matriz constitucional. Dada a amplitude do assunto, optou-se por fazer um recorte e abordar temas específicos. Assim, em um primeiro momento, tratou-se do sigilo nas fases do processo penal (sumario e juicio oral), referindo-se, ainda, ao sigilo nas deliberações judiciais. Após pesquisou-se o sigilo como proteção das testemunhas e peritos. Na sequência, o sigilo dos meios de obtenção de prova, especialmente na busca e apreensão; detenção e abertura de correspondência privada e interceptações telefônicas; circulação ou entrega vigiada; e agente encoberto ou infiltrado. Por fim, tratou-se do sigilo profissional.

PALAVRAS-CHAVE. Sigilo. Processo Penal Espanhol. Sumario e juicio oral. Testemunhas e peritos. Meios de obtenção de prova. Sigilo profissional.

ABSTRACT. This paper analyzes the secrecy in the Spanish Criminal Procedure, explaining, first, its constitutional matrix. Due to the amplitude of the subject, it was decided to focus on specific issues. So, at first, it was studied the secrecy in the criminal procedure phases (sumario and juicio oral), referring also to secrecy in judicial decisions. After, it was researched the secrecy as protection to witnesses and experts. Then, the secrecy in evidence collection means, such as search and seizure; mailing and telephone calls interceptions; undercover agent. Finally, the professional secrecy.

\footnotetext{
${ }^{1}$ Artigo recebido em 03/02/2016 e aprovado em 23/05/2016.
} 
Revista Eletrônica de Direito Processual - REDP.

Rio de Janeiro. Ano 10. Volume 17. Número 1. Janeiro a Junho de 2016

Periódico Semestral da Pós-Graduação Stricto Sensu em Direito Processual da UERJ

Patrono: José Carlos Barbosa Moreira. ISSN 1982-7636. pp. 46-66

http://www.e-publicacoes.uerj.br/index.php/redp/index

KEYWORDS. Secrecy. Spanish Criminal Procedure. Sumario and juicio oral. Witnesses and experts. Evidence collection means. Professional secrecy.

SUMÁRIO. 1. Introdução. 2. Sigilo nas fases do processo penal espanhol. 2.1. Sigilo no sumario. 2.2. Sigilo no juicio oral. 2.3 As deliberações judiciais e o sigilo. 3. Sigilo como tutela a testemunhas e peritos. 4. Sigilo e meios de obtenção de prova. 4.1. Da busca e apreensão. 4.2. Detenção e abertura de correspondência privada e as interceptações telefônicas. 4.3. Circulação ou Entrega vigiada (artigo 263 bis da Ley de Enjuiciamiento Criminal). 4.4. Do agente encoberto ou infiltrado (art. 282 bis da Ley de Enjuiciamiento Criminal). 5. Sigilo profissional. 6. Breve conclusão. 7. Referências Bibliográficas.

\section{Introdução}

O sigilo, na Espanha, possui notável matriz constitucional.

De fato, a Constituição Espanhola, em seu art. 18.1, tutela os direitos à honra, intimidades pessoal e familiar e à própria imagem. O parágrafo 2o mesmo artigo dispõe que o domicílio é inviolável, esclarecendo que "nenhuma entrada ou busca poderá ser feita sem o consentimento do titular ou decisão judicial, salvo em caso de flagrante delito". $\mathrm{Na}$ sequência ( $§ 30$ ), este dispositivo constitucional garante o segredo das comunicações, em especial das postais, telegráficas e telefônicas, sujeitando-os, ainda, a reserva de jurisdição.

Tutela a Constituição, no art. 18, o sigilo de dados, prescrevendo que "a lei limitará o uso da informática para garantir a honra e intimidade pessoal e familiar dos cidadãos e o pleno exercício de seus direitos" (§ 4o). ${ }^{2} \mathrm{O}$ art. 20.1, 'd', a seu turno, reconhece e protege o direito de comunicar-se ou receber livremente informação verdadeira por qualquer meio de difusão, sublinhando que a lei regulará o direito à cláusula de consciência e ao segredo profissional no exercício destas liberdades.

$\mathrm{O}$ artigo 17, por sua vez, reza que toda pessoa possui direito à liberdade e à segurança, prescrevendo ainda a Constituição terem todos direito a um processo público

\footnotetext{
${ }^{2}$ A Ley Orgánica 15/1999, de 13 de dezembro, regulamentou esse dispositivo constitucional, disciplinando a Proteção de Dados de Caráter pessoal.
} 
Revista Eletrônica de Direito Processual - REDP.

Rio de Janeiro. Ano 10. Volume 17. Número 1. Janeiro a Junho de 2016

Periódico Semestral da Pós-Graduação Stricto Sensu em Direito Processual da UERJ

Patrono: José Carlos Barbosa Moreira. ISSN 1982-7636. pp. 46-66

http://www.e-publicacoes.uerj.br/index.php/redp/index

(art. 24). Na mesma senda, o art. 120 reza que atos judiciais serão públicos, com as exceções previstas pelas leis processuais.

O cotejo destes dispositivos constitucionais, sua regulamentação legal, bem assim sua aplicação pelo Poder Judiciário Espanhol é o objeto deste trabalho.

$\mathrm{O}$ assunto, por deveras amplo, não comporta aqui esgotamento, pelo que se elegeu alguns temas específicos, intimamente ligados ao objetivo da pesquisa, que é avaliar se o processo penal espanhol tutela, a contento, o sigilo.

Nesta direção, tratar-se-á, primeiramente, do sigilo nas fases do processo penal espanhol, especialmente no sumario e juicio oral, fazendo-se referência, ainda, ao sigilo versus deliberações judiciais.

Na sequência, será analisado o sigilo como tutela das testemunhas e peritos.

No item 4, o sigilo na obtenção dos meios de prova, especificamente na busca e apreensão; na detenção e abertura de correspondência privada e interceptações telefônicas; na circulação ou entrega vigiada; e no agente encoberto ou infiltrado.

No último item serão feitas considerações sobre o sigilo profissional.

Finalmente, serão sintetizadas as principais conclusões deste estudo.

Impende registrar que na presente pesquisa serão utilizados os métodos dialético, dedutivo e comparístico. ${ }^{3}$

\section{Sigilo nas fases do processo penal espanhol}

Em breve síntese, o sistema processual penal espanhol é constituído de duas fases principais: sumario e juicio oral.

Pelo artigo 299 da Ley de Enjuiciamiento Criminal, o sumário é constituído das diligências destinadas a embasar o julgamento e praticadas para averiguar a existência do crime com todas as circunstâncias que possam influir em sua qualificação e na culpabilidade do sujeito ativo. É realizado perante o juiz de instrução.

Encerrada a fase investigativa, o juiz instrutor declarará findo o sumário e remeterá os autos ao tribunal competente para conhecer o delito (art. 622).

\footnotetext{
${ }^{3}$ O significado destes métodos são os propostos por MARCHI, Eduardo C. Silveira. Guia de metodologia jurídica. 2. edição. São Paulo: Saraiva, 2009, pp. 86-87. Assim método dialético é "análise e discussão das posições doutrinárias antagônicas em face de cada argumento ou problema”; método comparístico, a seu turno, a "abordagem do direito comparado".
} 
Revista Eletrônica de Direito Processual - REDP.

Rio de Janeiro. Ano 10. Volume 17. Número 1. Janeiro a Junho de 2016

Periódico Semestral da Pós-Graduação Stricto Sensu em Direito Processual da UERJ

Patrono: José Carlos Barbosa Moreira. ISSN 1982-7636. pp. 46-66 http://www.e-publicacoes.uerj.br/index.php/redp/index

Há então o juízo de admissibilidade da acusação, podendo, nesta etapa, ocorrer sobreseimiento, ou seja, a extinção da ação. Diversas são as hipóteses de sobreseimiento, especialmente : a) quando não existem indícios suficientes da prática da infração penal; b) quando o fato não constitui crime; c) quando incide causa excludente de ilicitude ou culpabilidade (art. 637).

Passada essa etapa, a causa é remetida para o juicio oral, fase em que são produzidas as provas propostas pelas partes e admitidas pelo Tribunal, realizados os debates e prolatada a sentença.

Não poderão ser produzidas provas não propostas pelas partes (art. 728), salvo as acareações, as diligências que o Tribunal considere necessárias para a comprovação de qualquer dos fatos objeto de julgamento, bem assim as provas tendentes a demonstrar a contradita manifestada em relação a alguma testemunha (art. 729).

$\mathrm{Na}$ fase do juicio oral, poderão as partes ler as diligências praticadas no sumario que, por causas independentes, não puderem ser reproduzidas na etapa do juicio oral (art. 730).

Produzidas as provas, passa-se aos debates.

Primeiramente tem a palavra o Ministério Público (art. 734), seguido do defensor do autor civil (se houver), que se limitará a tecer considerações sobre a responsabilidade civil (art. 735).

Na sequência, é dada a palavra aos defensores dos acusados e depois ao das pessoas civilmente responsáveis, se distintos (art. 736).

Após os debates, será facultado aos processados tecer alguma consideração, velando o Presidente para que não ofendam a moral nem faltem ao respeito devido ao Tribunal e a todas as pessoas, e cinjam-se ao que seja pertinente, cassando-lhes a palavra caso necessário (art. 739).

Os autos, então, são conclusos para sentença (art. 740), a ser prolatada no prazo legal pelo Tribunal (art. 741 e ss.).

\subsection{Sigilo no sumario}

No 'sumario', a regra geral é o sigilo externo e a publicidade interna, ou seja, apenas inter partes. 
Revista Eletrônica de Direito Processual - REDP.

Rio de Janeiro. Ano 10. Volume 17. Número 1. Janeiro a Junho de 2016

Periódico Semestral da Pós-Graduação Stricto Sensu em Direito Processual da UERJ

Patrono: José Carlos Barbosa Moreira. ISSN 1982-7636. pp. 46-66 http://www.e-publicacoes.uerj.br/index.php/redp/index

$\mathrm{O}$ art. 301 da Ley de Enjuiciamiento Criminal prescreve que as diligências serão secretas; já pelo artigo 302, as partes poderão tomar conhecimento das diligências e nelas intervir.

Sobre o tema, discorre VICENTE GIMENO SENDRA:

Tradicionalmente la fase instructora se há caracterizado desde siempre por estar informada por el principio del secreto de las actuaciones. Es más, desde el proceso penal inquisitivo y hasta la reforma operada por la Ley 53/1978 al art. 302 puede afirmarse que, em nuestro ordenamiento procesal penal regía el principio del secreto absoluto de la actividad sumarial, no solo con respecto a lós terceros y a la sociedad, sino también frente al propio imputado a quien se le efectuaba una instrucción 'a sus espaldas'.

La vigencia de dicho principio de secreto absoluto se justificaba, de un lado, en la necessidad de evitar las filtraciones de los actos de investigación, los cuales podrían prevenir a otros coimputados y, de otro, em la de 'compensar' la actividad del delincuente: si éste había tenido tiempo para planificar el delito, se le había de otorgar otro tanto a la sociedad para investigar el hecho punible (vide la Exposición de Motivos da LECrim).

La Ley 53/1978, al reformar el art. 302 e introducir el principio de publicidad relativa de la fase instructora (por ló demás, vigente ya em la práctica, ante la invención de al 'fotocopiadora'), cambió substancialmente esta filosofia, de tal suerte que, en la actualidad, sigue cobrando toda su vigencia la primera de las enunciadas funciones, esto es, la de asegurar el exito de la instrucción, en tanto que ha quedado abolida la segunda, como consecuencia del adelanto, que aquella Ley efectuó, del nascimiento del derecho de defensa a la fase instructora.

Por consiguinte, cabe afirmar que, en el momento actual, la función primordial del secreto instructorio consiste en garantizar el exito de la investigación sumarial, evitando las comunicaciones en 
Revista Eletrônica de Direito Processual - REDP.

Rio de Janeiro. Ano 10. Volume 17. Número 1. Janeiro a Junho de 2016

Periódico Semestral da Pós-Graduação Stricto Sensu em Direito Processual da UERJ

Patrono: José Carlos Barbosa Moreira. ISSN 1982-7636. pp. 46-66

http://www.e-publicacoes.uerj.br/index.php/redp/index

la causa que puedan provocar la fuga de los partícipes en el hecho

punible y/o la destrucción o manipulación de las fuentes de proba. ${ }^{4}$

Quem revelar indevidamente o segredo é apenado com multa de 250 a 2.500 pesetas.

Critica-se esta multa por ser absolutamente irrisória e insuficiente a garantir a inviolabilidade do sigilo. ${ }^{5}$

Caso o violador do segredo seja funcionário público, incorrerá também em responsabilidade penal. $\mathrm{O}$ art. 417 do Código Penal, inserido no título dos delitos contra a administração pública criminaliza a conduta do funcionário público infiel na custodia de documentos e violação de segredos. ${ }^{6}$

Registre-se que nem mesmo o advogado, procurador, membro do ministério público, juiz ou membro de tribunal escapam do enquadramento penal de suas condutas caso violem segredo processual.

O art. 466 do Código Penal, titulado De la obstrucción a la justicia y la deslealtad profesional, inserido no título dos delitos contra a administração da justiça, determina:

\section{“Artículo 466.}

1. El abogado o procurador que revelare actuaciones procesales declaradas secretas por la autoridad judicial, será castigado con las penas de multa de doce a veinticuatro meses e inhabilitación especial para empleo, cargo público, profesión u oficio de uno a cuatro años.

2. Si la revelación de las actuaciones declaradas secretas fuese realizada por el Juez o miembro del Tribunal, representante del Ministerio Fiscal, Secretario Judicial o cualquier funcionario al

\footnotetext{
${ }^{4}$ GIMENO SENDRA, Vicente; MORENO CATENA, Víctor; CORTÉS DOMÍNGUEZ, Valentín. Lecciones de derecho procesal penal. Madrid: Colex, 2001, p. 185.

5 GIMENO SENDRA, Vicente; MORENO CATENA, Víctor; CORTÉS DOMÍNGUEZ, Valentín. Lecciones..., cit., p. 186.

6 “Artículo 417. 1. La autoridad o funcionario público que revelare secretos o informaciones de los que tenga conocimiento por razón de su oficio o cargo y que no deban ser divulgados, incurrirá en la pena de multa de doce a dieciocho meses e inhabilitación especial para empleo o cargo público por tiempo de uno a tres años. Si de la revelación a que se refiere el párrafo anterior resultara grave daño para la causa pública o para tercero, la pena será de prisión de uno a tres años, e inhabilitación especial para empleo o cargo público por tiempo de tres a cinco años. 2. Si se tratara de secretos de un particular, las penas serán las de prisión de dos a cuatro años, multa de doce a dieciocho meses, y suspensión de empleo o cargo público por tiempo de uno a tres años".
} 
Revista Eletrônica de Direito Processual - REDP.

Rio de Janeiro. Ano 10. Volume 17. Número 1. Janeiro a Junho de 2016

Periódico Semestral da Pós-Graduação Stricto Sensu em Direito Processual da UERJ

Patrono: José Carlos Barbosa Moreira. ISSN 1982-7636. pp. 46-66

http://www.e-publicacoes.uerj.br/index.php/redp/index

servicio de la Administración de Justicia, se le impondrán las penas

previstas en el artículo 417 en su mitad superior.

3. Si la conducta descrita en el apartado primero fuere realizada por cualquier otro particular que intervenga en el proceso, la pena se impondrá en su mitad inferior."

O artigo 302 também traz exceção à regra geral do sigilo interno no sumário, aduzindo que o juiz pode, por decisão fundamentada (STC 13/1985) decretar segredo às partes, mas esta providência é cabível apenas nos delitos de ação pública e por tempo não superior a um mês, devendo o segredo ser levantado necessariamente pelo menos dez dias antes da conclusão do sumário.

O segredo sumarial possui, inegavalmente, fundamento constitucional.

Pelo artigo $1^{\mathrm{o}}$ da Constituição Espanhola, a justiça é um dos valores superiores de seu ordenamento jurídico.

O artigo 17, a seu turno, reza que toda pessoa possui direito à liberdade e à segurança.

De outro lado, protege-se, com o segredo sumarial, a honra, intimidade e imagem do investigado, valores também com dignidade constitucional (art. 18).

O Conselho Geral do Poder Judiciário, em 25.01.95, declarou:

El Consejo General del Poder Judicial entiende que el secreto sumarial ordinario - y solo la especial e temporal declaración de secreto del sumario incluso las partes - debe ser escrupulosamente respetado, sin que esse respeto implique menoscabo de la libertad de información, sino elemental protección de bienes e derechos que han de armonizarse con dicha libertad. El secreto sumarial es, en efecto, además de instrumento de eficacia en la reconstrucción de los hechos presuntamente delictivos, garantía del derecho al honor de las personas que, en algún momento del proceso, puedan aparecer relacionadas con aquellos hechos, en tanto estos se esclarecen a efecto de formular, o no, una acusación jurisdicionalmente contrastada. Este es el fundamento de las normas legales que imponen ese secreto y son de insoslayable cumplimiento. 
Revista Eletrônica de Direito Processual - REDP.

Rio de Janeiro. Ano 10. Volume 17. Número 1. Janeiro a Junho de 2016

Periódico Semestral da Pós-Graduação Stricto Sensu em Direito Processual da UERJ

Patrono: José Carlos Barbosa Moreira. ISSN 1982-7636. pp. 46-66

http://www.e-publicacoes.uerj.br/index.php/redp/index

Como adverte GIMENO SENDRA, "tal y como declarado la jurisprudencia, tanto del TC (STC 176/1988), como del TS (STS 2 de deciembre de 1987) el derecho 'a un proceso público' del art. 24.2 CE no se proyecta em este estadio procesal. Dicho derecho fundamental es tan solo predicable del juicio oral, sin que exista un derecho incondicional del imputado a la publicidad relativa de la fase instructora".

\subsection{Sigilo no juicio oral}

No juízo oral, a regra geral é a publicidade plena. Realmente, o art. 301 da Ley de Enjuiciamiento Criminal reza que as diligências serão secretas até a abertura do juicio oral. O art. 649, a seu turno, prescreve que, iniciada essa fase, "serão públicos todos os atos do processo".

Essa determinação está em plena consonância com a Constituição Espanhola, que prescreve terem todos direito a um processo público (art. 24).

$\mathrm{O}$ art. 120, a seu turno, diz que atos judiciais serão públicos, com as exceções previstas pelas leis processuais.

Nessa seara, portanto, a restrição à publicidade constitui-se exceção.

Pelo art. 680 da Ley de Enjuiciamiento Criminal, os debates serão públicos, sob pena de nulidade.

Por seu parágrafo único, todavia, as sessões, por decisão judicial motivada, poderão ser realizadas a portas fechadas quando assim o exijam "razões de moralidade ou ordem pública, o devido respeito à pessoa ofendida pelo delito ou a sua família”.

A decretação desse sigilo, todavia, não abrange as vítimas, os réus, o acusador privado, o autor civil e respectivos defensores, que poderão acompanhar a solenidade (art. 681).

Prevê, a lei, ainda, a expulsão do recinto das pessoas que se comportarem indevidamente (art. 684).

A despeito de pública a fase do juicio oral, frisa MARIA TERESA RODRÍGUES VALLS que os terceiros interessados na informação contida no procedimento penal deverão,

\footnotetext{
7 GIMENO SENDRA, Vicente; MORENO CATENA, Víctor; CORTÉS DOMÍNGUEZ, Valentín. Lecciones..., cit., p. 187-188.
} 
Revista Eletrônica de Direito Processual - REDP.

Rio de Janeiro. Ano 10. Volume 17. Número 1. Janeiro a Junho de 2016

Periódico Semestral da Pós-Graduação Stricto Sensu em Direito Processual da UERJ

Patrono: José Carlos Barbosa Moreira. ISSN 1982-7636. pp. 46-66

http://www.e-publicacoes.uerj.br/index.php/redp/index

para sua obtenção, cumprir o contido no art. 4 do Regulamento n. 1/2005 do CGPJ, ou seja,

apresentar por escrito o pedido à Secretaria do Órgão Judicial, indicando os documentos cujo conhecimento se solicita e expondo a causa de seu interesse. Por esse mecanismo, fica o Secretário Judicial obrigado a valorar se este terceiro cumpre a condição de interessado, valendo anotar que de acordo com a jurisprudência do Tribunal Constitucional o interesse deve ser legítimo e relacionado diretamente com o assunto de que se pretenda obter a informação (Sentenças de 03.03.95 e 06.06.01). ${ }^{8}$

Outrossim, o Real Decreto de 95/2009, de 06 de fevereiro (BOE de 7 de fevereiro de 2009) instituiu o SIRAJ (Sistema de Registros Administrativos de Justicia), integrado pelo Registro Central de Apenados, Registro Central para a Proteção de Vítimas de Violência Doméstica, Registro Central de Medidas Cautelares, Registro Central de Rebeldes Civis e Registro de Sentenças de Responsabilidade Penal dos Menores. Suas informações são acessíveis aos órgãos judiciais; ao Ministério Público ${ }^{9}$; aos interessados que, fornecendo sua identidade, poderão solicitar o acesso; bem assim à polícia judiciária. ${ }^{10}$

\subsection{As deliberações judiciais e o sigilo}

Pelo art. 350 da Ley de Enjuiciamiento Criminal, a discussão e votação das sentenças será realizado a portas fechadas.

Já as sentenças, além de motivadas, serão pronunciadas em audiência pública (art. 120).

\section{Sigilo como tutela a testemunhas e peritos}

\footnotetext{
${ }^{8}$ Principio de publicidad procesal y derecho a la protección de datos de carácter personal: aproximación a la problemática actual en juzgados y tribunales españoles. La ley penal: revista de derecho penal, procesal y penintenciario, Madri, v. 7, n. 71, maio/2010.p. 76-77.

${ }^{9}$ Sobre o papel do Ministério Público na proteção de dados, v. FRÍAS MARTíNEZ, Emilio. Protección y tratamiento de datos personales por el Ministerio Fiscal. La ley penal: revista de derecho penal, procesal y penintenciario, Madri, v. 7, n. 71, p. 13-30, maio/2010.

${ }^{10}$ AYJÓN, Miguel Marcos. El sistema de registros administrativos de apoyo a la administración de justicia y la protección de los datos. La ley penal: revista de derecho penal, procesal e penitenciario, Madrid, v. $7, \mathrm{n}$. 71, maio/2010, p. 32-33.
} 
Revista Eletrônica de Direito Processual - REDP.

Rio de Janeiro. Ano 10. Volume 17. Número 1. Janeiro a Junho de 2016

Periódico Semestral da Pós-Graduação Stricto Sensu em Direito Processual da UERJ

Patrono: José Carlos Barbosa Moreira. ISSN 1982-7636. pp. 46-66

http://www.e-publicacoes.uerj.br/index.php/redp/index

A Ley 19/94, de Protección a Testigos y Peritos en Causas Criminales, prevê uma série de medidas destinadas à preservação da identidade das testemunhas ou peritos, seus endereços residencial/profissional e profissão, sem prejuízo do contraditório à defesa.

Pela exposição de motivos desta lei, "la experiencia diaria pode de manifesto en algunos casos las reticencias de los ciudadanos a colaborar com la policía judicial y con la Administración de Justicia en determinadas causas penales ante el temor a sufrir represalias"

Assim é que poderá não haver menção nos atos processuais a qualquer dado que sirva à sua identificação, podendo essas pessoas comparecer para a prática de qualquer diligência utilizando qualquer procedimento que impeça sua identificação visual normal (art. 2, 'a').

Prevê a lei, ainda, a possibilidade de fixação de seu endereço como a sede do órgão judicial, que lhe remeterá reservadamente as citações e notificações necessárias (art. 2, 'c').

Essas medidas são aplicáveis mediante decisão judicial fundamentada, caso exista perigo grave para a integridade física, liberdade ou patrimônio dos interessados, seu cônjuge/companheiro, ascendentes, descendentes ou irmãos (art. $\left.1^{\circ}\right)$.

Outrossim, os membros das forças de segurança, do Ministério Fiscal e a autoridade judicial evitarão que se fotografe ou capte por qualquer outro meio a imagem de peritos e testemunhas, inclusive podendo retirar o material fotográfico, cinematográfico ou de qualquer outro tipo de quem infringir esta proibição (art. 3).

Importante frisar, como o faz a exposição de motivos da lei, que as garantias em favor dos peritos e testemunhas não são de caráter absoluto e ilimitado, sendo a mens legis o necessário equilíbrio entre o direito a um processo com todas as garantias e a tutela dos direitos fundamentais dos peritos, testemunhas e seus familiares.

\section{O sigilo e os meios de obtenção de prova}

\subsection{Da busca e apreensão}

A inviolabilidade do domicílio é consagrada pela Constituição Espanhola em seu art.18, que explica não ser viável o ingresso sem o consentimento do proprietário ou com mandado judicial, salvo caso de flagrante delito. 
Revista Eletrônica de Direito Processual - REDP.

Rio de Janeiro. Ano 10. Volume 17. Número 1. Janeiro a Junho de 2016

Periódico Semestral da Pós-Graduação Stricto Sensu em Direito Processual da UERJ

Patrono: José Carlos Barbosa Moreira. ISSN 1982-7636. pp. 46-66

http://www.e-publicacoes.uerj.br/index.php/redp/index

A Ley de Enjuiciamiento Criminal regulamenta a busca e apreensão nos artigos 545 a 574 .

Pode ser decretada pelo juiz quando houver indícios de que no local esteja o autor do crime ou seus instrumentos ou vestígios, além de outros objetos que possam servir para sua descoberta ou comprovação (e.g. livros, papéis).

Em se cuidando, porém, de livros e papéis contábeis, a busca e apreensão é apenas permitida quando houver indícios graves de que esta diligência redundará no descobrimento de algum fato ou circunstância importante da causa (art. 573).

A busca em edifícios e locais públicos pode ser feita de dia ou de noite (art. 546).

A lei define como edifícios ou locais públicos (art. 547):

a) os que estiverem destinados a qualquer serviço oficial, militar ou civil do Estado, da Província ou do Município, ainda que habitem ali os encarregados do respetivo serviço ou os da conservação ou custódia do edifício ou lugar;

b) os que estiverem destinados a qualquer espécie de reunião ou diversão, sejam ou não lícitos;

c) quaisquer outros edifícios ou lugares fechados que não constituírem domicílio de um particular;

d) a frota naval do Estado.

Também a busca domiciliar pode ser feita de dia ou de noite. Não consentido o morador em sua realização, será notificado da decisão judicial motivada que a autorizou em até vinte e quatro horas (art. 550).

O consentimento poderá ser expresso ou tácito (art. 551).

A decisão que determinar a busca domiciliar deve especificar: a) o lugar dela objeto; b) se deve ser feita durante o dia; c) a autoridade ou funcionário dela incumbida (art. 558).

Reputam-se domicílio (art. 554):

a) os palácios reais, estejam ou não habitados pelo Monarca;

b) o edifício ou lugar fechado, ou a parte destinada à moradia de qualquer espanhol ou estrangeiro residente na Espanha e de sua família;

c) a frota naval nacional mercante.

Dispunha originalmente a Ley de Enjuiciamiento Criminal não constituírem domicílio dos que ali se encontrem ou residam temporariamente as tavernas, restaurantes, pousadas e bares (art. 557). 
Revista Eletrônica de Direito Processual - REDP.

Rio de Janeiro. Ano 10. Volume 17. Número 1. Janeiro a Junho de 2016

Periódico Semestral da Pós-Graduação Stricto Sensu em Direito Processual da UERJ

Patrono: José Carlos Barbosa Moreira. ISSN 1982-7636. pp. 46-66

http://www.e-publicacoes.uerj.br/index.php/redp/index

Esta disposição legal, sem embargo, foi declarada inconstitucional pela Sentença do

Tribunal Constitucional n. 10/2002, de 17 de janeiro (B.O.E. N. 34, Suplemento de 8 de fevereiro de 2002).

A busca deve ser feita evitando-se as inspeções inúteis, procurando não prejudicar nem importunar o interessado mais que o necessário, e adotar-se-ão todo o gênero de precauções para não comprometer sua reputação, respeitando-se seus segredos se não interessarem à instrução (art. 552).

O artigo 553, a seu turno, dispõe que a prisão de pessoas poderá ser efetuada quando haja expedição de mandado de prisão contra elas ou sejam surpreendidas em flagrante delito, inclusive quando um criminoso, imediatamente perseguido pelos agentes da autoridade, ocultar-se e em alguma casa. Regulamenta, portanto, a exceção constitucional que autoriza a busca domiciliar independentemente de decisão judicial. Dispõe referido artigo, ainda, que nesses casos o resultado da diligência será comunicado imediatamente ao juiz.

A busca será sempre feita presença do interessado, ou de pessoa que legitimamente o represente; à sua falta, na presença de um indivíduo de sua família maior de idade; havendo impossibilidade, na presença de duas testemunhas, vizinhos do mesmo bairro (art. 569).

\subsection{Detenção e abertura de correspondência privada e as interceptações telefônicas}

A Constituição Espanhola, em seu artigo 18.3, garante o "segredo das comunicações, em especial das postais, telegráficas e telefônicas, salvo decisão judicial”.

O que protege o dispositivo, como bem observa GIMENO SENDRA, é a comunicação, e não o comunicado, que poderá ser legitimamente difundido por algum dos partícipes da relação informativa, salvo se afete o direito à intimidade. ${ }^{11}$

Em se cuidando de interceptação telefônica, o sigilo da comunicação engloba também a identidade dos comunicantes e outros aspectos externos, como, p. ex., seu momento, duração e destino. ${ }^{12}$

11 GIMENO SENDRA, Vicente; MORENO CATENA, Víctor; CORTÉS DOMÍNGUEZ, Valentín. Lecciones..., cit., p. 237.

${ }^{12}$ MATTALÍN EVANGELIO, Ângela. El efecto expansivo de los derechos fundamentales a la intimidad y al secreto de las comunicaciones telefónicas. In: FERNÁNDEZ HERNÁNDEZ, Antonio (Coord.). Nuevas amenazas a la seguridad nacional: terrorismo, criminalidad organizada y tecnologias de la información y la comunicación. Valencia: Tirant lo Blanch, 2013, p. 383. 
Revista Eletrônica de Direito Processual - REDP.

Rio de Janeiro. Ano 10. Volume 17. Número 1. Janeiro a Junho de 2016

Periódico Semestral da Pós-Graduação Stricto Sensu em Direito Processual da UERJ

Patrono: José Carlos Barbosa Moreira. ISSN 1982-7636. pp. 46-66 http://www.e-publicacoes.uerj.br/index.php/redp/index

A detenção e abertura de correspondência postal e telegráfica implica a interrupção da comunicação, a qual é impedida de chegar ao destinatário; já a interceptação telegráfica e telefônica não interrompe a comunicação, apenas captando seu conteúdo. ${ }^{13}$

A Ley de Enjuiciamiento Criminal regulamenta o dispositivo constitucional no seu artigo 579 e seguintes.

Poderá haver a quebrada do sigilo postal, telegráfico ou telefônico, por decisão judicial motivada ${ }^{14}$, quando houver indícios de que por este meio se descubra ou se comprove algum fato ou circunstância importante da causa ( $\S 1^{\circ}$ e $2^{\circ}$ do art. 579).

A decisão deve especificar o objeto da intervenção (delito apurado), a pessoa alvo, além do meio ou meios de comunicação alcançados pela medida.

Se no curso da interceptação telefônica, por exemplo, se descobrir crime diverso do investigado, deve dar-se notícia ao juiz competente, e somente após decisão motivada é que se poderá continuar a investigar esse novo delito, já que ocorrendo divergência entre o delito objeto de investigação e o de fato investigado haverá ilicitude da intervenção (STC 49/1996 e SSTEDH de 24.04.90 [caso Kruslin]).

A diligência, ademais, deve ser excepcional, de modo que havendo outras alternativas menos gravosas de investigação deve-se optar por elas (SSTS de 23.02.94), bem assim é cabível apenas em relação a delitos graves (SSTS de 12.01.95).

Também por decisão judicial motivada, por um prazo de três meses, prorrogáveis por iguais períodos, poderá haver o monitoramento das comunicações em foco das pessoas sobre as quais existam indícios de responsabilidade criminal $\left(\S 3^{\circ}\right)$.

Em caso de urgência, quando as investigações se relacionem a delitos perpetrados por quadrilhas armadas ou terroristas, o monitoramento poderá ser ordenado pelo Ministro do Interior ou, à sua falta, pelo Secretário de Segurança do Estado, com comunicação imediata, escrita e motivada ao juiz competente, que no prazo de setenta e duas horas, também motivadamente, ratificará ou revogará a decisão $\left(\S 4^{\circ}\right)$.

\subsection{Circulação ou Entrega vigiada (artigo 263 bis da Ley de Enjuiciamiento Criminal)}

13 GIMENO SENDRA, Vicente; MORENO CATENA, Víctor; CORTÉS DOMÍNGUEZ, Valentín. Lecciones..., cit., p. 242.

${ }^{14}$ Porquanto a decisão é limitativa de um direito fundamental (STEDH, caso Kopp, de 25.03.98). 
Revista Eletrônica de Direito Processual - REDP.

Rio de Janeiro. Ano 10. Volume 17. Número 1. Janeiro a Junho de 2016

Periódico Semestral da Pós-Graduação Stricto Sensu em Direito Processual da UERJ

Patrono: José Carlos Barbosa Moreira. ISSN 1982-7636. pp. 46-66 http://www.e-publicacoes.uerj.br/index.php/redp/index

Entende-se por circulação ou entrega vigiada a técnica consistente em permitir que remessas ilícitas ou suspeitas de drogas ou outras substâncias proibidas circulem pelo território espanhol, saiam ou entrem sem interferência obstativa da autoridade e seus agentes e sob sua vigilância, com o fim de descobrir ou identificar as pessoas envolvidas na prática de algum delito relativo a ditas drogas ou substâncias, assim como também prestar auxílio à autoridade estrangeira com esses mesmos fins.

Este instituto foi introduzido na LECrim pela LO 8/1992, em cumprimento ao art. 11.1 da Convenção de Viena e art. 73 da Convenção de Schengen.

Como explica GIMENO SENDRA, "en efecto, tal y como se ha avanzado el art. 408 del CP castiga la conducta de la autoridad o funcionario que, faltando a la obligación de su cargo, dejare intencionalmente de promover la persecución de los delitos. Pero la lucha contra la criminalidad organizada exige que, tratándose de delitos contra la salud pública, la policía permita la entrada y/o la circulación de estupefacientes por nuestro país a fin de poder determinar y aprehender al máximo número de integrantes de tales bandas relacionadas com el narcotráfico. Como quiera que el art. 262 da LECrim establece la obligación de denunciar todo hecho punible y el art. $408 \mathrm{CP}$ constituye su reverso, al sancionar penalmente el incumplimiento de esta obligación, de no haberse incluído el art. 263 bis em la LECrim, el funcionario de policía incurriría em responsabilidad penal si no cumpliera con su obligación de denunciar e detener al responsable de la primera comisión de uno de los tales delitos, lo que conllevaría una perdida de eficacia en la lucha contra dicha criminalidad organizada". ${ }^{15}$

O juiz de instrução competente e o Ministério Público, assim como os chefes das Unidades Orgânicas da Polícia Judiciária, centrais ou de âmbito provincial, e seus superiores poderão autorizar a circulação ou entrega vigiada de entorpecentes, assim como de outras substâncias proibidas.

Esta medida deve ser determinada por decisão fundamentada em que se especifique, quando possível, o objeto de autorização ou entrega vigiada, assim como o tipo ou quantidade de substância tratada.

$\mathrm{Na}$ adoção destas medidas, levar-se-á em conta sua necessidade aos fins da investigação, bem assim a gravidade do delito e as possibilidades de vigilância.

15 GIMENO SENDRA, Vicente; MORENO CATENA, Víctor; CORTÉS DOMÍNGUEZ, Valentín. Lecciones..., cit., p. 250. 
Revista Eletrônica de Direito Processual - REDP.

Rio de Janeiro. Ano 10. Volume 17. Número 1. Janeiro a Junho de 2016

Periódico Semestral da Pós-Graduação Stricto Sensu em Direito Processual da UERJ

Patrono: José Carlos Barbosa Moreira. ISSN 1982-7636. pp. 46-66 http://www.e-publicacoes.uerj.br/index.php/redp/index

A autoridade emissora da ordem comunicará imediatamente ou Ministério Público e, se já existente procedimento judicial, ao juiz de instrução competente.

\subsection{Do agente encoberto ou infiltrado (art. 282 bis da Ley de Enjuiciamiento Criminal)}

Consoante lição de VÍCTOR MORENO CATENA, "la medida de investigación de los agentes encubiertos o infiltrados consiste en la entrada de uno o varios agentes de las Fuerzas de Seguridad, devidamente autorizados a tal fin, como miembros de una organización criminal y su participación en el entramado de la misma, con objeto de descubrir las acciones delictivas pasadas, prevenir las futuras y lograr la desaparición y el castigo de la banda, con todos los elementos que la integran. Esta figura ha sido regulada en nuestro Derecho por la LO5/1999, de 13 de enero, que introdujo el art. 282 bis de la LECrim, avalada por las disposiciones del CEDH (sentencia de 15 junio 1992 [caso Ludi])". ${ }^{16}$

Dessa forma, pelo art. 282 bis da Ley de Enjuiciamiento Criminal, na investigação da delinquência organizada, o juiz de instrução competente ou o Ministério Público, com comunicação imediata ao primeiro, poderão autorizar funcionários da polícia judiciária, mediante decisão fundamentada e tendo em conta a necessidade aos fins da investigação, a atuar sob outra identidade e adquirir e transportar objetos, produtos ou instrumentos do crime, bem assim deferir a sua infiltração.

A “identidade suposta" será outorgada pelo Ministério do Interior pelo prazo de seis meses prorrogáveis por iguais períodos, ficando os agentes legitimamente habilitados para atuar em tudo relacionado à investigação e a praticar negócios jurídicos e participar da vida social sob esta identidade.

A decisão ventilada deverá consignar o nome verdadeiro do agente e a identidade atribuída. Esta decisão será sigilosa e será arquivada em apartado.

As informações obtidas pelo agente encoberto deverão com a maior brevidade possível ser comunicadas a quem autorizou a investigação. Elas, ademais, serão acostadas ao feito e valoradas livrememente pelo juiz competente.

16 GIMENO SENDRA, Vicente; MORENO CATENA, Víctor; CORTÉS DOMÍNGUEZ, Valentín. Lecciones..., cit., p. 214-215. 
Revista Eletrônica de Direito Processual - REDP.

Rio de Janeiro. Ano 10. Volume 17. Número 1. Janeiro a Junho de 2016

Periódico Semestral da Pós-Graduação Stricto Sensu em Direito Processual da UERJ

Patrono: José Carlos Barbosa Moreira. ISSN 1982-7636. pp. 46-66

http://www.e-publicacoes.uerj.br/index.php/redp/index

Os funcionários da polícia que houverem atuado na investigação com identidade falsa poderão manter essa identidade ao prestar depoimento no feito respectivo.

Nenhum funcionário poderá ser obrigado a atuar como agente encoberto.

Considera-se delinquência organizada, para os fins destes institutos, a associação de três ou mais pessoas para praticar, de forma permanente ou reiterada, condutas que tenham por fim cometer algum dos delitos arrolados no $\S 4^{\circ}$ do art. 282 bis da Ley de Enjuiciamiento Criminal, in verbis:

“a) Delitos de obtención, tráfico ilícito de órganos humanos y trasplante de los mismos, previstos en el artículo 156 bis del Código Penal.

b) Delito de secuestro de personas previsto en los artículos 164 a 166 del Código Penal.

c) Delito de trata de seres humanos previsto en el artículo 177 bis del Código Penal.

d) Delitos relativos a la prostitución previstos en los artículos 187 a 189 del Código Penal.

e) Delitos contra el patrimonio y contra el orden socioeconómico previstos en los artículos 237, 243, 244, 248 y 301 del Código Penal.

f) Delitos relativos a la propiedad intelectual e industrial previstos en los artículos 270 a 277 del Código Penal.

g) Delitos contra los derechos de los trabajadores previstos en los artículos 312 y 313 del Código Penal.

h) Delitos contra los derechos de los ciudadanos extranjeros previstos en el artículo 318 bis del Código Penal.

i) Delitos de tráfico de especies de flora o fauna amenazada previstos en los artículos 332 y 334 del Código Penal.

j) Delito de tráfico de material nuclear y radiactivo previsto en el artículo 345 del Código Penal.

k) Delitos contra la salud pública previstos en los artículos 368 a 373 del Código Penal. 
Revista Eletrônica de Direito Processual - REDP.

Rio de Janeiro. Ano 10. Volume 17. Número 1. Janeiro a Junho de 2016

Periódico Semestral da Pós-Graduação Stricto Sensu em Direito Processual da UERJ

Patrono: José Carlos Barbosa Moreira. ISSN 1982-7636. pp. 46-66

http://www.e-publicacoes.uerj.br/index.php/redp/index

1) Delitos de falsificación de moneda, previsto en el artículo 386 del

Código Penal, y de falsificación de tarjetas de crédito o débito o cheques de viaje, previsto en el artículo 399 bis del Código Penal.

m) Delito de tráfico y depósito de armas, municiones o explosivos previsto en los artículos 566 a 568 del Código Penal.

n) Delitos de terrorismo previstos en los artículos 572 a 578 del Código Penal.

o) Delitos contra el patrimonio histórico previstos en el artículo 2.1.e de la Ley Orgánica 12/1995, de 12 de diciembre, de represión del contrabando.

O agente encoberto estará isento de responsabilidade criminal pelas condutas que sejam consequência necessária do desenvolvimento da investigação, sempre que guardem a devida proporcionalidade com a sua finalidade e não constituam uma provocação ao crime.

\section{Sigilo Profissional.}

O ordenamento espanhol tutela o sigilo profissional.

A Constituição Espanhola, no art. 20.1, 'd', reconhece e protege o direito de comunicar-se ou receber livremente informação verdadeira por qualquer meio de difusão, sublinhando que a lei regulará o direito à cláusula de consciência e ao segredo profissional no exercício destas liberdades.

$\mathrm{O}$ art. 416.2, da LECrim, prescreve que estão dispensados da obrigação de depor $o$ advogado do imputado a respeito dos fatos que lhe foram confiados por sua qualidade de defensor.

$\mathrm{O}$ art. 417 do mesmo diploma, a seu turno, reza que não poderão ser obrigados a declarar como testemunhas: a) os eclesiásticos e ministros de cultos religiosos, sobre os fatos que lhes forem revelados no exercício de seu ministério; b) os funcionários públicos, tanto civis quanto militares, de qualquer classe, quando não puderem declarar sem violar o segredo que por razão de seus cargos estiverem obrigados a guardar, ou quando, procedendo em virtude de obediência devida, não forem autorizados por seu superior hierárquico para prestar a declaração que se lhes peça. 
Revista Eletrônica de Direito Processual - REDP.

Rio de Janeiro. Ano 10. Volume 17. Número 1. Janeiro a Junho de 2016

Periódico Semestral da Pós-Graduação Stricto Sensu em Direito Processual da UERJ

Patrono: José Carlos Barbosa Moreira. ISSN 1982-7636. pp. 46-66

http://www.e-publicacoes.uerj.br/index.php/redp/index

$\mathrm{O}$ art. 199 do Código Penal criminaliza a conduta daquele que revela segredo profissional, in verbis:

\section{“Artículo 199.}

1. El que revelare secretos ajenos, de los que tenga conocimiento por razón de su oficio o sus relaciones laborales, será castigado con la pena de prisión de uno a tres años y multa de seis a doce meses.

2. El profesional que, con incumplimiento de su obligación de sigilo o reserva, divulgue los secretos de otra persona, será castigado con la pena de prisión de uno a cuatro años, multa de doce a veinticuatro meses e inhabilitación especial para dicha profesión por tiempo de dos a seis años."

Postas estas premissas, cabe asseverar que a natureza jurídica do sigilo profissional é mista, ou seja, penal material (seara em que é elemento normativo do tipo do art. 199 do Código Penal), deontológica (vem regulamentado pelos códigos de ética das mais variadas profissões), e processual, tanto civil quanto penal.

Saliente-se que as disposições em comento vedam apenas o depoimento acerca de fatos conhecidos em razão da função, ministério, ofício ou profíssão. Com relação a quaisquer outros, há o dever de depor.

Caso prestado depoimento com revelação de segredo profissional, terá havido a produção não só de uma prova ilegítima (em violação à norma processual referida), mas também ilícita (por em afronta à intimidade constitucionalmente tutelada, bem assim ao art. 199 do Código Penal Espanhol).

\section{Breve conclusão.}

Pretendeu-se, no presente trabalho, analisar o sigilo no processo espanhol, esclarecendo, primeiramente, sua matriz constitucional, apresentando os dispositivos que a ele aludem, explícita ou implicitamente.

A amplitude do assunto não permitiria sua adequada abordagem neste singelo texto, de modo que se optou por fazer um recorte e abordar temas específicos. 
Revista Eletrônica de Direito Processual - REDP.

Rio de Janeiro. Ano 10. Volume 17. Número 1. Janeiro a Junho de 2016

Periódico Semestral da Pós-Graduação Stricto Sensu em Direito Processual da UERJ

Patrono: José Carlos Barbosa Moreira. ISSN 1982-7636. pp. 46-66 http://www.e-publicacoes.uerj.br/index.php/redp/index

Dessarte, analisou-se, em um primeiro momento, o sigilo nas fases do processo penal, ou seja, no sumario e juicio oral, aludindo-se, ainda, ao sigilo nas deliberações judiciais.

No terceiro item, averiguou-se o sigilo como proteção das testemunhas e peritos.

Posteriormente, o sigilo na obtenção dos meios de prova, especialmente na busca e apreensão; na detenção e abertura de correspondência privada e interceptações telefônicas; na circulação ou entrega vigiada; e no agente encoberto ou infiltrado.

Por fim, tratou-se do sigilo profissional.

Com essas breves linhas, procurou-se trazer panorama geral de como o sigilo é disciplinado pelo direito processual penal espanhol, seja no que tange à sua regulamentação constitucional e infraconstitucional, bem assim no tocante a seu tratamento pela doutrina e jurisprudência espanholas.

Conclui-se tratar-se de sistema de garantias sofisticado e que atende suficientemente ao que se espera de um ordenamento jurídico na tutela deste fundamental valor social.

Diante do exposto, o objetivo da pesquisa foi cumprido a contento.

\section{REFERÊNCIAS BIBLIOGRÁFICAS}

ARMENTA DEU, Thereza. La prueba ilícita (um estúdio comparado). Madrid: Marcial Pons, 2009.

ASENCIO MELLADO, Jose Maria. Prueba proibida y prueba preconstituida. Madrid: Trivium, 1989.

ÁVILA, Cynthia; FERNANDÉZ, Eduardo Carlos; H. LAGO, Daniel. El sistema procesal penal español. In: HENDLER, Edmundo S. Sistemas procesales penales comparados. Buenos Aires: Ad-hoc, 1999.

AYJÓN, Miguel Marcos. El sistema de registros administrativos de apoyo a la administración de justicia y la protección de los datos. La ley penal: revista de derecho penal, procesal e penitenciario, Madrid, v. 7, n. 71, p. 31-37, maio/2010.

CONRADI, Faustino Gutiérrez -Alviz (org.). La criminalidad organizada ante la justicia. Sevilha: Universidad de Sevilha, 1996.

FERRER BELTRAN, Jordi. La valoración racional de la prueba. Madrid: Marcial Pons, 2007.

. Prueba y verdad en el derecho. 2. edição. Madrid: Marcial Pons, 2005. 
Revista Eletrônica de Direito Processual - REDP.

Rio de Janeiro. Ano 10. Volume 17. Número 1. Janeiro a Junho de 2016

Periódico Semestral da Pós-Graduação Stricto Sensu em Direito Processual da UERJ

Patrono: José Carlos Barbosa Moreira. ISSN 1982-7636. pp. 46-66

http://www.e-publicacoes.uerj.br/index.php/redp/index

FRÍAS MARTÍNEZ, Emilio. Protección y tratamiento de datos personales por el Ministerio

Fiscal. La ley penal: revista de derecho penal, procesal y penintenciario, Madri, v. 7, n. 71, p. 13-30, maio/2010.

GARCÍA, Maria Dolores Delgado. El agente incubierto: técnicas de investigación. Problemática e legislación comparada. In: CONRADI, Faustino Gutiérrez -Alviz (org.). La criminalidad organizada ante la justicia. Sevilha: Universidad de Sevilha, 1996, p. 66-84.

GIMENO SENDRA, Vicente. Le intercettazioni telefoniche in Spagna. In: Archivio Penale, Roma, 2/3, p. 145-153, fev.mar/1994.

GIMENO SENDRA, Vicente; MORENO CATENA, Víctor; CORTÉS DOMÍNGUEZ, Valentín. Lecciones de derecho procesal penal. Madrid: Colex, 2001.

GRINOVER, Ada Pelegrini; GOMES FILHO, Antonio Magalhães; SCARANCE FERNANDES, Antonio. As nulidades do Processo Penal. 8. edição. São Paulo: Revista dos Tribunais, 2005.

LEÃO DE SOUZA, Diego Fajardo Maranha. Sigilo profissional e prova penal. In Revista Brasileira de Ciências Criminais, São Paulo, n. 73, p. 107-155, jul-ago/2008.

MARCHI, Eduardo C. Silveira. Guia de metodologia jurídica. 2. edição. São Paulo: Saraiva, 2009.

MATTALÍN EVANGELIO, Ângela. El efecto expansivo de los derechos fundamentales a la intimidad y al secreto de las comunicaciones telefónicas. In: FERNÁNDEZ HERNÁNDEZ, Antonio (Coord.). Nuevas amenazas a la seguridad nacional: terrorismo, criminalidad organizada y tecnologias de la información y la comunicación. Valencia: Tirant lo Blanch, 2013, p. 379-407.

NAVARRETE, Antonio Maria Lorca. Derecho procesal penal. 2a ed. Madri: Editorial Tecnos, 1988.

PENALVA, Ernesto Pedraz. Publicidad e derecho al deludo proceso. In: CONRADI, Faustino Gutiérrez -Alviz (org.). La criminalidad organizada ante la justicia. Sevilha: Universidad de Sevilha, 1996, p. 157-190.

RAMOS MÉNDEZ, Francisco. El proceso penal. Lectura constitucional. Barcelona: Bosh, 1991.

RODRÍGUEZ VALLS, María Teresa. Principio de publicidad procesal y derecho a la protección de datos de carácter personal: aproximación a la problemática actual en juzgados 
Revista Eletrônica de Direito Processual - REDP.

Rio de Janeiro. Ano 10. Volume 17. Número 1. Janeiro a Junho de 2016

Periódico Semestral da Pós-Graduação Stricto Sensu em Direito Processual da UERJ

Patrono: José Carlos Barbosa Moreira. ISSN 1982-7636. pp. 46-66

http://www.e-publicacoes.uerj.br/index.php/redp/index

y tribunales españoles. La ley penal: revista de derecho penal, procesal y penintenciario,

Madri, v. 7, n. 71, p. 73-80, maio/2010.

QUIROGA, Jacobo López Barja de. Tratado de derecho procesal penal. Navarra: Arazandi, 2004. 